\title{
Infrastructure and Coffee Exports' Fluctuations in a Small Open Economy: Case of Togolese Economy
}

\author{
Tom-Irazou Tchalim \\ Enseignant-Chercheur à la Faculté des Sciences Economiques et de Gestion de l'Université de Kara, Kara, Togo \\ Email: mathieuthom@yahoo.fr
}

How to cite this paper: Tchalim, T.-I. (2016) Infrastructure and Coffee Exports' Fluctuations in a Small Open Economy: Case of Togolese Economy. Modern Economy, 7, 1419-1427.

http://dx.doi.org/10.4236/me.2016.712130

Received: September 23, 2016

Accepted: November 5, 2016

Published: November 8, 2016

Copyright $\odot 2016$ by author and Scientific Research Publishing Inc. This work is licensed under the Creative Commons Attribution International License (CC BY 4.0).

http://creativecommons.org/licenses/by/4.0/

\begin{abstract}
In the current context of boosting economic growth based on agriculture, the traditional determinants seem insufficient. It is therefore necessary to establish the role of non-classical factors that influence the evolution of agricultural exports. Thus, this paper aims to establish the role of transportation infrastructure in determining coffee exports in Togo's economy. Firstly, the principal component analysis technique is used to construct a proxy of transportation infrastructure. Then the Error Correction Model is estimated under the gravity model framework. The data used in this study come mainly from FAO database, World Bank database and cover the period 1980-2014. The results reveal that transportation infrastructure is a good pillar for coffee exports enhancement in the short and long run. In addition, domestic production has a positive and significant effect on coffee exports. Regarding global factors, only the exchange rate affects long-term coffee exports. In terms of policy message, increase in transportation infrastructure investment is a strategy for increasing coffee exports.
\end{abstract}

\section{Keywords}

Coffee, Export, Gravity Model, Togo

\section{Introduction}

Agriculture is the mainstream economic activity in many developing countries. The economic performance in these countries is highly associated with the development of this sector. The sector performances trend in Togo is partly defined by coffee chain. However, in recent years, the coffee exports have recorded a discouraging trend. Indeed, Togo's coffee exports have declined by $23.4 \%$ during the agricultural year 2011/ 2012 , and by $31.4 \%$ during the campaign 2012/2013 [1]. Many efforts aiming to reverse this trend have not been successful as one can deduct from the bellow Figure 1. 


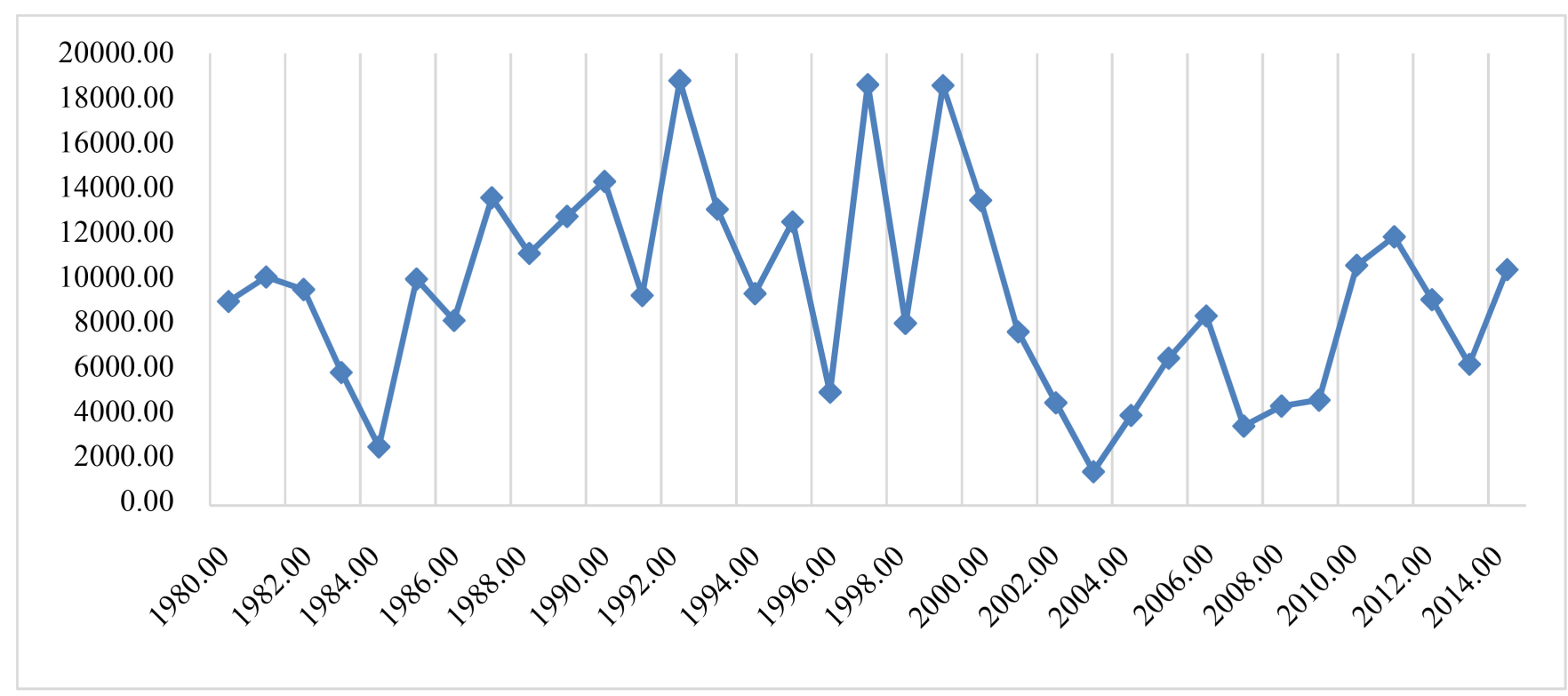

Figure 1. Evolution of coffee exports in Togo from 1980 to 2014. Source: Author construction from FAOSTAT data.

Thus, the traditional coffee exports drivers seem insufficient to achieve a higher and sustainable coffee exports. Consequently, new coffee exports drivers are needed and infrastructure development may be one of them since deficiencies in transportation and related infrastructure may translate into poorly functioning domestic markets with little spatial and temporal integration, low price transmission, and weak international competitiveness. The impact of infrastructure on coffee export is missing in most of the studies focusing on coffee exports. Such a study is merely inexistent in the context of Togo. This research tries to fill this paramount gap.

This paper is structured in three parts. After a detailed presentation of the review of literature in the following section, the Section 3 discusses the model used while the last section deals with the analysis of the results. The paper ends with a conclusion.

\section{Literature Review}

Among the Objectives of Sustainable Development adopted recently, the fight against poverty is of paramount importance. Several development policies are developed and implemented to overcome this persisting challenge. However, even though significant progress has been made in some parts of the world in terms of poverty reduction, much remains to be done especially in Least Developed Countries (LDCs).

Agriculture is at the heart of the economy of the Least Developed Countries (LDCs). It represents a large share of Gross Domestic Product (GDP) (30\% to 60\%), and employs a significant proportion of the working population ( $40 \%$ to $90 \%$ in most cases). It is the only source of substance and income for more than half of the population of those [2]. In view of these findings it appears that the LDCs will not move towards economic growth and reduction of poverty if they do not value human resources and potential productive capacity in agriculture. Faced with the challenge of globalization 
and international competition, food production and a strong agricultural system would therefore be a key pillar of economic growth and development in LDCs. This justifies the World Bank twin goals ${ }^{1}$.

Indeed, although globalization offers new opportunities for growth and development in all regions of the world, the hopes and expectations has raised the rapid liberalization of trade and financial markets have not yet materialized particularly in LDCs. In fact the latter are increasingly marginalized, especially in the agricultural trade. The combined share of their agricultural exports declined from about 5\% of the world total in the early 70s to just 1\% in 1996-98 [3]. Furthermore LDCs export a narrow range of primary commodities vulnerable to fluctuations in demand and worsening terms of trade. Also their external debt remains too heavy. The inability of LDCs to compete not only in global markets but also on domestic markets is reflected in the increase in import bills for food products; raising and the establishment of a true agricultural development policy in order to reverse the trend.

Togo, the study country, falls within the least developed countries. The Togolese economy is mainly based on agriculture which employs $70 \%$ of the working population, provides $40 \%$ of GDP (Gross Domestic Product), far ahead of the services and trade, which accounted for $23 \%$ and $1 \%$ of GDP. It also represents $20 \%$ of export earnings (Ministry of Agriculture, 2012). The three main export crops are cotton, cocoa and coffee. Indeed, after fifteen years of economic stagnation due to the socio-political unrest in the country from 1990 to 2005, a period that saw also the suspension of much of the international aids, Togo is experiencing since 2007 a political stability and economic revival phase. The Togolese agriculture appears primarily as farming unproductive subsistence; the level of food production has changed little and annuity products faced the vagaries of world markets. Cotton is a crop grown in all regions of Togo in rotation with food crops. As for coffee and cocoa, they are grown mainly west of the Plateaux region and, to a lesser extent, in the southwest of the central region. The reform of the sector, which occurred in June 1996, focused on the liberalization of prices of coffee and cocoa, and marketing (including export) that were previously under the control of a public marketing board agricultural products. The main objectives of liberalization were to improve incentives to producers and their income. The coffee chain management and cocoa is currently provided by a Steering Committee composed of representatives of all operators involved in these sectors: state, producers, exporters and banks. The Committee determines, every two weeks, a producer price (Price) on the basis of the evolution of international prices and certain costs; the target price is $70 \%$ of the price fob. There has been since 2005 a cocoa prices rise (almost 22\% from the 2004 level), (source: Trade Policy Review, WT/TPR/S/166, page 48-72).

However, even if exports of cotton and cocoa have seen a remarkable rise in recent decades, in terms of monetary value, coffee export stagnated or even declined. Moreover, statistical analyzes show that the average growth rate of green coffee production

${ }^{1}$ The World Bank has committed itself to twin goals: eliminating extreme poverty by 2030 and boosting shared prosperity. 
over the past decade is $-9.4 \%$ (Ministry of Agriculture, 2012) due both to a continued decline in acreage and aging plantations. A decline in production results in lower coffee exports.

So this is designed to analyze the various internal and external factors that may affect coffee exports in Togo in order to develop a recovery strategy for this sector since it is vital to the economic growth of the country.

The analysis is based on the standard gravity model linking the various factors that may affect trade in coffee exports. Considered as the most appropriate model in the analysis of trade flows, the gravity model allows taking into account the specificity of developing countries in capturing the impact of various factors on coffee exports in Togo.

\section{Methodology}

\subsection{Conceptual Framework}

The model used for the analysis of Togolese coffee exports was inspired from the gravity model. The gravity model allows, taking into account the specificity of the Togolese economy, to capture the impact of various factors on coffee exports of the latter.

The model became in recent decades the standard modeling model of international trade [4] and indifferently realized exchanges between similar economies or very different based on theoretical foundations as far as monopolistic competition and comparative advantage. The gravity model originates from the theory of universal gravitation.

Indeed, the mathematician and physicist Isaac [5] presents the results of its work in mechanical formula and the law of universal gravitation that two bodies attract with a force proportional to the product of their masses and inversely proportional to the square the distance that separates them. Under the algebraic form this law is expressed as follows:

$$
F_{i j}=G * M_{i} M_{j} / D_{i j}^{2}
$$

where $F_{i j}$ is the force of attraction, $M_{i}$ represents the mass of $i, M_{j}$ is the mass of $j, D_{i j}$ is the distance between $i$ and $j, G$ is the gravitational constant. In 1962 economists discovered gravity through the work of $J$. Tinbergen that formalizes the law as follows:

$$
F_{i j}=G \times\left(M_{i}\right)^{y}\left(M_{J}\right)^{z} /\left(D_{i j}\right)^{k}
$$

where $k, F_{i j}$ is the flow of trade in value of country $i$ to country $j, M_{i}$ and $M_{j}$ are the economic weight of the two economies $i$ and $j$ (measured by GDP), $D_{i j}$ is the geographical distance between them. $y, z$ and $k$ are elasticities.

\subsection{Functional Form of the Gravitational Model}

Let's consider two countries $i$ and $j$, the respective GDP $Y_{i}$ and $Y_{j}$ and the distance $d_{i j}$;

The export flows from i to $j$ is $X_{i j}$. We have: 


$$
X_{i j}=f\left(Y_{i}, Y_{j}, d_{i j}\right)=g \cdot\left(Y_{i}\right)^{y}\left(Y_{j}\right)^{z} /\left(d_{i j}\right)^{k}
$$

The general form of the gravity equation is obtained by applying the logarithm.

$$
\ln X_{i j}=a+y \ln Y_{i}+z \ln Y_{j}-k \ln d_{i j}+\varepsilon_{i j}
$$

With $y, z$ and $k$ positive. Log transformation allows to reduce the power function in a linear function, and apply as OLS (Ordinary Least Squares) in the econometric treatment. It also helps to interpret the coefficients in terms of elasticity. Finally, the estimated equation is obtained by including control variables base on the literature on the topic in the previous equation and removing some variables. The estimated form is specified in the following section.

\subsection{Estimates Procedure}

According [6] and [7], the first main feature of gravitational models is its flexibility in the sense that one can add or remove variables in the model. The second main feature is the symmetry, i.e., we can apply these models to analyze the trade in one direction only (unilateral trade) or in both directions (bilateral trade). The gravity model is consequently used in this study to assess the impact of infrastructure on coffee exports in Togo. The functional form of the estimated model is specified as follow (Table 1):

$$
\ln \left(\exp _{t}\right)=a+b \ln \left(\operatorname{prod}_{t}\right)+c \ln \left(\text { price }_{t}\right)+d \ln \left(\text { exch }_{t}\right)+e \ln \left(\text { infrs }_{t}\right)+f \ln \left(G D P_{t}\right)+\varepsilon_{i j}
$$

The coefficients of the log-linear regression supply elasticities of trade flows with respect to various explanatory variables considered. The $\mathcal{E}_{i}$ residues correspond to differences in theoretical model and can identify, from an economic point of view, potential or saturation levels (according to the sign of the residue) exchanges. The interpretation of the modeling results is made according to the standard criteria of regression and analysis of variance [8] based on correlation coefficients, significance tests and the variance inflation factor values and using graphics and exploratory methods [9]. Exports are firstly employed in domestic production and also foreign demand [10]. We deduce that green coffee production coefficient of Togo in year $t$ is positive and the world coffee exports coefficient in year $t$ is negative.

Given that much of international trade is now intra-firm trade, we believe that for-

\begin{tabular}{|c|c|}
\hline Variables & Description \\
\hline $\exp _{t}$ & Quantity of coffee exported in year $t$ \\
\hline $\operatorname{prod}_{t}$ & Quantity of coffee produced in year $t$ \\
\hline price $_{t}$ & Coffee export price in the year $t$ \\
\hline $\operatorname{exch}_{t}$ & US dollar exchange rate in CFA in year $t$ \\
\hline Infrs_index $x_{t}$ & Infrastructure index in the year $t$ \\
\hline$G D P_{t}$ & Gross domestic product in the year $t$ \\
\hline
\end{tabular}
eign direct investment plays positively on exports. However, given the specificity of

Table 1. Variables description. 
the area studied and the particularity of the country (there is seldom multinational companies that invest directly in agriculture, support for agriculture is often the fact of the state and development partners), we will use instead of IDE public spending as a whole. But to reflect the effect of public spending on coffee exports, we will consider our work in the amount of coffee produced nationally. The inclusion of this variable follows the hypothesis that increased spending on agriculture would promote an increase in production which in turn would support an increase in agricultural exports. Thus, the expected sign of the variable national coffee production quantity will be positive.

[11] showed that the price F.O.B. consists of farm gate prices and various internal taxes, transaction costs, transportation and marketing negatively affect the export volume of property. We therefore hope that the price variable is negatively correlated to the quantity exported green coffee.

According to [12], plus the local currency depreciates against the currency in which the exchange is more price competitiveness of local products improves. It is therefore hoped a positive correlation between the exchange rate of the US dollar and the CFA green coffee exports in Togo.

The co-integration approach is used in this study to estimate equation [13]. It is divided into four main stages: The first stage is the analysis of the variables stationary. This is to determine very carefully the type of deterministic or stochastic trend of each variable and their respective order of integration. Dickey-Fuller tests are used for this purpose. Step 2 is that of the cointegration test. It is appropriate here to determine the number of cointegration relations. Decisions are made according to the test results of [14] [15] based on the eigenvalues. Step 3 involves identifying cointegrating relationships, estimating by ordinary least squares (OLS) in long-term relationships between the variables and checking the residue stationary. Finally in the last step, short-term relationships between the variables are estimated by OLS. All these steps are performed with the Eviews software.

\subsection{Data Source}

The data used in this study are essentially time series data and covering the period from 1980 to 2014. Data on the quantities produced, quantities exported, world exports and FOB prices are from the FAO database (FAOSTAT). The exchange rate, population and GDP and the variables included in the construction of infrastructure index are taken from the database of the World Bank.

\section{Results and Discussion}

Before estimating the gravity model we first construct the transportation infrastructure index using the principal component analysis technique. This proxy is supposed to capture the overall transportation infrastructure development of the country. The variables included in this process are rail miles, road miles and investment in transportation 
infrastructure. Both the Kaiser-MeyerOlkin $\left(\mathrm{KMO}^{2}\right)$ measure of sampling adequacy and Bartlett's test of sphercity (Hair, et al., 1998) indicated that all the three variables included for the factor analysis were relevant. The constructed proxy is then included in the gravity model to capture the impact of transportation infrastructure on coffee exports. The descriptive statistics of the constructed proxy as well as the other variables are presented in the Table 2 .

\subsection{Estimate by Error Correction Model (ECM)}

Analysis of the results of our estimates by an Error Correction Model is preceded by a brief analysis of stationarity tests and co-integration of our data.

The results of stationarity tests indicate that the variables are integrated of order 1 . The tests are conducted at the 5\% threshold. This leads us to make the cointegration tests of Johansen, the results show that the variables are co-integrated on the period from 1982 to 2011 with a rank of co-integration that is $5 \%$ to $10 \%$ threshold. The estimation results are presented in the Table 3.

The Table 3 shows the results of short and long term estimates of the export model. It is observed that the coefficient associated with the restoring force is negative $(-0.4608)$ and significantly different from zero at the $1 \%$ level (the Student statistic is $-4.353>-1.96)$. So there is an error correction mechanism. $46.08 \%$ of the imbalance between the desired and actual level of exports can be adjusted. In other words, a shock found during a year is completely absorbed after 2 years and 2 months.

\subsection{Resilience of Short and Long Term}

The results of the estimates reveal that the transportation infrastructure development is closely associated with the level of coffee exports. Indeed, a 10\% increase of the transportation infrastructure index results in $2.35 \%$ increase in coffee export in the short run, this figure becomes $4.52 \%$ in the long run.

For all the remaining variables, the expected signs of the coefficients are not all met.

Table 2. Descriptive statistics of the variables.

\begin{tabular}{cccccc}
\hline Variables & Count & Mean & Max & Min & Sd \\
\hline Infrs_index & 34 & 3.47 & 5.56 & 0.55 & 1.30 \\
lnexp & 34 & 9.14 & 9.84 & 7.30 & 3.06 \\
lnGDP & 34 & 10.63 & 14.4 & 9.34 & 1.35 \\
lnprod & 34 & 9.35 & 10.12 & 7.89 & 1.90 \\
lnprice & 34 & 7.28 & 8.08 & 6.36 & 0.54 \\
lnexch & 34 & 6.11 & 6.59 & 5.35 & 0.20 \\
\hline
\end{tabular}

Source: Author's calculation based on data from WDI and FAOSTAT.

${ }^{2}$ Kaiser-Meyer-Olkin (KMO) is a statistics that measures the adequacy of a variable to be included in factor analysis based on correlation and partial correlation. There is a KMO statistic for each individual variable, and their sum is the KMO overall statistic. KMO varies from 0 to 1.0 and KMO overall should be 0.60 or higher to proceed with factor analysis. 
Table 3. Estimation results of the ECM.

\begin{tabular}{|c|c|c|}
\hline Control variables & Coefficients & t-values \\
\hline Constante & 6.915 & 0.714 \\
\hline $\operatorname{DLn}(\mathrm{GDPt})$ & -0.748 & -0.543 \\
\hline DLn(PRICEt) & $0.10^{* *}$ & 2.020 \\
\hline DLn(PRODt) & $0.413^{*}$ & 2.110 \\
\hline DLn(EXCHGt) & -0.21 & -0.489 \\
\hline D(INFRT_INDEX) & $0.235^{* * *}$ & 2.43 \\
\hline $\operatorname{Ln}(\operatorname{EXPT}(-1))$ & $-0.408^{* * *}$ & -4.353 \\
\hline $\operatorname{Ln}(\operatorname{GDPt}(-1))$ & -0.196 & -0.547 \\
\hline $\operatorname{Ln}($ PRICEt $(-1)$ & 0.088 & 0.290 \\
\hline $\operatorname{Ln}(\operatorname{PRODt}(-1))$ & $1.194^{* * *}$ & 2.560 \\
\hline $\operatorname{Ln}(\mathrm{EXCHGt}(-1))$ & $-0.657^{*}$ & -1.758 \\
\hline INFRST_INDEXt(-1) & $0.452^{* *}$ & 1.99 \\
\hline R-Carré & \multicolumn{2}{|c|}{0.79} \\
\hline Fisher. stat & \multicolumn{2}{|c|}{5.98} \\
\hline
\end{tabular}

${ }^{*}=$ significant at $10 \% ;{ }^{* *}=$ significant at $5 \% ;{ }^{* *}=$ significant at $1 \%$. Source: Author, estimates in stata.

GDP, contrary to the basic assumption, has a negative effect on the Togolese coffee exports both in the short term and long term, but this effect is not significant. Regarding national quantities produced, there is a positive effect on the domestic exports of Togolese coffee, a result which confirms the predictions of economic theory as a country that can export only what it produces, any increase in production would lead to a rise in exports. Regarding external variables, we observe that the coffee export price has a positive effect on exports of coffee only in the short term. By contrast, the exchange rate has negative impact in the long run on coffee exports bill.

Specifically, a $10 \%$ higher exchange rate causes a decrease in coffee exports of $6.57 \%$ in the long run while an increase in coffee export price at the same rate causes, in the short run, a $0.10 \%$ increase in exports.

\section{Conclusions}

Agricultural exports are one of the main sources of funding of Togo, but they are subject to strong cyclical fluctuations. It is therefore necessary to establish the role of non-classical factors that influence the evolution of agricultural exports. Thus, this paper established the role of transportation infrastructure in determining coffee exports in Togo's economy. Firstly, the principal component analysis technique is used to construct a proxy of transportation infrastructure. Then the Error Correction Model is estimated under the gravity model framework. The data used in this study come mainly from FAO database, World Bank database and cover the period 1980-2014.

The results of the estimates suggest that transportation infrastructure is a driver of coffee exports in Togo in a short term as well as in the long term. Coffee price, exchange rate, and national production are other drivers of coffee exports established by 
this study. The policy message drawn from this study encourages policy makers in investing in transportation infrastructure as a sound strategy to boost coffee exports.

\section{References}

[1] FAOSTAT (2015) http://faostat3.fao.org/download/Q/QC/E

[2] African Development Bank (2010) Infrastructure Deficit and Opportunities in Africa. http://www.afdb.org/fileadmin

[3] Anderson, K. and Valenzuela, E. (2008) Estimates of Global Distortions to Agricultural Incentives, 1955 to 2007. Banquemondiale, Washington DC.

[4] Beard, N. and Swinbank, A. (2001) Decoupled Payments to Facilitate CAP Reform. Food Policy, 26, 121-145. http://dx.doi.org/10.1016/S0306-9192(00)00041-5

[5] Ravallion, M. (2001) On the Urbanization of Poverty. Document de travail sur le développement rural No. 2568, Banque Mondiale, Washington DC.

[6] Devereux, S. (2002) Social Protection for the Poor: Lessons from Recent International Experience. Document de travail IDS 142.

[7] Timmer, P. (2008) Agriculture and Pro-Poor Growth: An Asian Perspective. Asian Journal of Agriculture and Development, Southeast Asian Regional Center for Graduate Study and Research in Agriculture, 5, 1-28. http://dx.doi.org/10.2139/ssrn.1114155

[8] Timmer, P. (1988) The Agriculture Transformation. Handbook of Development Economics, Vol. 1, Elsevier Science Publishers B.V.

[9] Annabi, N. and Rajhi, T. (2001) Dynamics of Trade Liberalization: An Intertemporal General Equilibrium Model Applied to Tunisia. Présenté à la conférence: Policy Modeling for the European and Global Issues, Bruxelles.

[10] Swinbank, A. and Tranter, R., Eds. (2004) A Bond Scheme for Common Agricultural Policy Reform. CABI Publishing, Wallingford.

[11] Gohin, A., Gorin, O., Guyomard, H. and Le Mouël, C. (1999) Interprétation économique, avantages et limites du principe de découplage des instruments de soutien des revenus agricoles. Notes et études Economiques, 10, 9-37.

[12] Christiaensen, L., Demery, L. and Kuhl, J. (2011) The (Evolving) Role of Agriculture in Poverty Reduction-An Empirical Perspective. Journal of Development Economics, 96, 239254. http://dx.doi.org/10.1016/j.jdeveco.2010.10.006

[13] Schmitt, G. (1990) Is Structural Change Really a Source of Economic Growth? The Case of Agriculture. Journal of Institutional and Theoretical Economics (JITE), 146, 470-499.

[14] Singh, R., Haacker, M. and Lee, K. (2009) Determinants and Macroeconomic Impact of Remittances in Sub-Saharan Africa. IMF Working Paper WP/09/216.

http://dx.doi.org/10.5089/9781451873634.001

[15] Zinsou, J. and Adegbola, P. (2010) Analyse des determinants des exportations béninoises de noixd'anacarde. The Joint $3 r$ d African Association of Agricultural Economists ( $A A A E)$ and 48th Agricultural Economists Association of South Africa (AEASA) Conference, Cape Town, 19-23 September 2010. 
Submit or recommend next manuscript to SCIRP and we will provide best service for you:

Accepting pre-submission inquiries through Email, Facebook, LinkedIn, Twitter, etc.

A wide selection of journals (inclusive of 9 subjects, more than 200 journals)

Providing 24-hour high-quality service

User-friendly online submission system

Fair and swift peer-review system

Efficient typesetting and proofreading procedure

Display of the result of downloads and visits, as well as the number of cited articles

Maximum dissemination of your research work

Submit your manuscript at: http://papersubmission.scirp.org/

Or contact me@scirp.org 